EGU21-5525

EGU General Assembly 2021

(c) Author(s) 2021. This work is distributed under

the Creative Commons Attribution 4.0 License.

\title{
Infiltration processes in karst aquifers affected by large-scale forest disturbances
}

\author{
Urša Vilhar ${ }^{1}$, Mitja Ferlann ${ }^{1}$, Janez Kermavnar ${ }^{1}$, Erika Kozamernik ${ }^{1}$, Aleksander Marinšek ${ }^{1}$, Metka \\ Petrič $^{2,3}$, Tanja Pipan ${ }^{2,3}$, Daniel Žlindra ${ }^{1}$, and Nataša Ravbar ${ }^{2,3}$ \\ ${ }^{1}$ Gozdarski inštitut Slovenije / Slovenian Forestry Institute, Forest ecology department, Ljubljana, Slovenia \\ (ursa.vilhar@gozdis.si) \\ ${ }^{2}$ ZRC SAZU, Karst Research Institute, Titov trg 2, SI - 6230 Postojna, Slovenia \\ ${ }^{3}$ UNESCO Chair on Karst Education, University of Nova Gorica, Glavni trg 8, SI - 5271 Vipava, Slovenia
}

Karst systems represent $10-15 \%$ of land surface in the world and supply around $25 \%$ of the global demand for drinking water. In Slovenia karst areas are merely covered by forest and important for their rich and unique ecosystems. However, prevailing beech and mixed fir-beech forests in the region have been exposed to severe large-scale disturbances in the past few years, e.g., ice storms and heavy snow, windthrow, severe and prolonged periods of droughts and secondary insect damage, which have caused episodes of forest decline. Modification of the vegetation cover indirectly impacts the water balance. Despite the important role of karst water resources for supplying the population with drinking water, few studies exist that adequately evaluate the impact of predicted global changes on their quantity and quality. The effects of large-scale forest disturbances have been only marginally addressed, despite evaporation of water from the soil and epikarst being recognized as a significant process affecting hydrological cycle in karst regions. In many hydrological studies, the role and importance of vegetation in infiltration mechanisms, in particular the effect of trees and their root networks, has been widely neglected. In this study we present a holistic approach to infiltration processes research. An in-situ environmental monitoring network of the atmosphere-vegetation-soil-unsaturated zone of the aquifer has been designed to better understand infiltration in different compartments of the karst aquifer. Special focus is given to different forest development phases after large-scale disturbances and karst terrain morphology. The amount of precipitation in the open, canopy interception in mature forest and in canopy gaps with varying forest development phases, soil moisture and soil temperature are measured on the surface and subsurface. These measurements are performed in the area of an eLTER site Postojna-Planina cave system, i.e., on the top and bottom of karst depressions, while in the underground water discharge and electrical conductivity are measured in cave drips. By observing the time lag of the measured parameters to the recharge events, the effective infiltration of precipitation into the aquifer is evaluated and quantified. The results enabled to distinguish the recharge conditions under different forest development phases after large-scale disturbances and under different geomorphological conditions. The findings will in the later stage of the research serve as an input information for coupled vegetation-hydrological modelling of recharge conditions. Upscaling the modelling results from local to entire catchment scale would be useful for the evaluation of impacts of large-scale forest disturbance on the water balance of the 
entire karst aquifer system. 